\title{
Willingness to pay for improved residential waste management in a developing country
}

\author{
E. E. Ezebilo
}

Received: 3 November 2011/Revised: 22 December 2012/Accepted: 29 December 2012/Published online: 13 February 2013

(C) Islamic Azad University (IAU) 2013

\begin{abstract}
In most developing countries policies and frameworks that govern solid waste management strategies have often been directed at the waste management service providers and less attention is often given to the demand side of the problem. This paper reports a study regarding householders' willingness to pay for improved residential solid waste management. The data for the study originated from a contingent valuation survey that was conducted in 236 households in Ilorin city in Kwara State, Nigeria. A binary logit model was used to account for some factors influencing the respondents' willingness to pay. The results show that more than $80 \%$ of the respondents were in support of the residential waste management. The respondents were willing to pay an average of 3,660 Nigerian Naira (US \$24) each year. Income, education, dwelling type and whether the respondent is satisfied with private sector participation in provision of waste management service positively influenced the respondents' willingness to pay. The price, gender, household size and activities of sanitary inspectors had negative influence. The findings from this study could contribute to the knowledge regarding the design of a more sustainable residential waste management strategy in Nigeria and other countries that have similar conditions.
\end{abstract}

Keywords Contingent valuation - Dichotomous choice · Logit model · Urban waste management $\cdot$ Sustainability

E. E. Ezebilo $(\square)$

Southern Swedish Forest Research Centre, Swedish University of Agricultural Sciences, Box 49, 23053 Alnarp, Sweden e-mail: eugene.ezebilo@slu.se

\section{Introduction}

The increase in consumption, the use of disposable products and excessive packaging are creating increasing challenges for waste management authorities $(\mathrm{Ku}$ et al. 2009). Several policy instruments regarding solid waste management have been proposed. These include the command and control (Slack et al. 2009), i.e. waste regulation which is often accompanied by penalties in case of noncompliance. Command and control instruments have been found not to necessarily lead to compliance and improvement in environmental quality (Stafford 2002) and thus not very effective. The market-based instruments have been found to be more effective than the command and control (Driesen 2006) because it provides several incentives for individuals. For example, negative incentives such as revenue tax or 'pay as you throw' policies where the public pay according to the volume or weight of their waste; positive incentives, i.e. funding opportunities or tax reduction is applied for those whose activities lead to waste minimization (Gellynck and Verhelst 2007). There is also a market-based instrument which is a mix of negative and positive incentive, e.g. the deposit-refund systems (Wagner and Arnold 2008; Mckerlie et al. 2006). The voluntarybased instruments (e.g. voluntary participation in recycling) have also been implemented in many communities (Werner et al. 1995; Palatnik et al. 2005).

Although there are many policy instruments regarding solid waste management their effectiveness may vary between communities. For example, the 'pay as you throw' policy may not be very successful in some developing countries where the actual volume of solid waste generated by households are not well known (Longe and Ukpebor 2009). Thus, the price regarding solid waste management services is often based on a flat rate fixed by waste 
management authorities and paid monthly by each household. It will be interesting to explore how much money that households would be willing to pay for an improvement in waste management services and consequently environmental quality. The improvement in environmental quality has the characteristics of environmental good (e.g. good that its economic value is not revealed in market prices), i.e. non-excludability and non-rivalry (Hanley et al. 2007). Once the good is produced it is practically impossible to prevent anyone from consuming it and the same unit of the good can be consumed by more than one person. The waste management services are often under priced or non-priced because the economic benefits are not easily inferred from ordinary market (Anaman and Jair 2000). The economic benefits of waste management services are typically estimated by non-market valuation method such as the contingent valuation (Mitchell and Carson 1989; Loomis 1993; Bishop et al. 1995; Ezebilo 2010; Carson 2004; Ezebilo et al. 2010; Shih and Chou 2011; Imandoust and Gadam (2007). It uses survey questions to elicit people's preferences for non-market goods by asking them how much they would be willing to pay for specified improvements or to avoid decrements in them (Mitchell and Carson 1989). Several studies that have been carried out in developing countries have shown that willingness to pay amount, age, income, household size, occupation and educational level influence household willingness to pay for solid waste management (Rahji and Oloruntoba 2009; Chuen-Khee and Othman 2010; Alta and Deshaz 1996; Niringiye and Omortor 2010; Yusuf et al. 2007). Rahji and Oloruntoba (2009) applied the contingent valuation method (CVM) to predict determinants of household willingness to pay for solid waste management in Ibadan, Nigeria. They found that some factors such as income, asset owned, occupation and the payment amount influence willingness to pay. In their (Chuen-Khee and Othman 2010) study of economic values of household preferences for solid waste disposal in Malaysia, using the CVM, they found that age, ownership of house and income influence willingness to pay for solid waste disposal options. Alta and Deshaz (1996) applied the CVM in their study of households' demand for improved solid waste management in Gujarwala, Pakistan and found that quantity of waste generated by households, household size and age influences willingness to pay. In their (Niringiye and Omortor 2010) study of the determinants of willingness to pay for solid waste management in Uganda, using the CVM, they found that age influences willingness to pay. Yusuf et al. (2007) also used the CVM to estimate the economic value of improved household waste management in Oyo state, Nigeria. They found that price of waste management services, age, educational level, income and household size influence willingness to pay. The present paper contributes to the existing literature regarding the application of the CVM in eliciting preferences information of households' willingness to pay for household waste management services in developing countries. The willingness to pay could be used in determining the benefit of involving private firms in residential waste management. Apart from the commonly used variables in the published literature, the paper includes factors such as activities of sanitary inspectors and travel time to waste collection points to predict willingness to pay for improved residential waste management services.

The knowledge of the households' demand for solid waste management services is important in developing sustainable waste management strategy. This is important because the success of the strategy is to a large degree dependent on acceptance by the households. The Ilorin city, Nigeria, has overtime being faced with the problem of how best to manage household solid waste. Although during the period of this study a government agency and a private firm (contracted by the government) were in charge of household waste management in the Ilorin city, the problem of effective waste disposal persists. The government agency plays a supervisory role, while the private firm is in charge of collection and disposal of household solid waste. Because only one private firm is involved in the provision of the household waste management services the firm has less incentive to supply the quality of services required by consumers (i.e. households) because the private firm lacks the economic competition to do so. On the other hand, if more private firms are involved in the provision of the residential waste management services it should help increase effectiveness and consumers' (households) satisfaction due to competition between firms. This study provides insight into householders' willingness to pay for residential waste management which involves many private firms to improve the present waste management situation in Ilorin city, Nigeria. The pre-test and main surveys for the study were conducted in April, June and July 2009, respectively in Ilorin city, Nigeria.

\section{Materials and methods}

Ilorin, the capital of Kwara State, Nigeria, has an area of $100 \mathrm{~km}^{2}$ (Kwara State of Nigeria 1997). Like many traditional cities in Nigeria, Ilorin retains the characteristics of traditional town alongside a modern urban centre. The city can be classified into three sub-areas (Aderamo 2000), i.e. old residential area, new residential area and government reservation area. The old residential area is the indigenous part of Ilorin which is located in the central core area. The new residential area is the post-colonial area located around the core area of the city, while the government reservation area is the high-status neighbourhood area. The 
three delineated areas are mixed in terms of income groups. For example, there are some pockets of high-income neighbourhoods in the 'indigenous' part of the city, as well as pockets of low-income neighbourhoods in the 'government reservation area' part of the city (Ezebilo and Animasaun 2011). Various types of human activities thrive in Ilorin. The activities include agriculture, trading, transportation and a host of other professions. The human population of Ilorin was estimated to be 766,000 in 2006 (National Population Commission 2006). This study was conducted in Ilorin city because of the urbanization and the increasing waste disposal problems in the city (Awomuti 2008).

\section{Survey design and data collection}

The data collection was made by means of hand-delivered questionnaires and interviews. People who had no formal education were interviewed based on the questions in the questionnaire while people who had formal education were handed a copy of the questionnaire. Prior to the main survey group discussions and pre-test survey were conducted in April 2009. For the group discussions three community heads (one each from the sub-areas of Ilorin), three heads of women groups (one each from the sub-areas of Ilorin) and four youth leaders, i.e. two males and two females were invited for group discussion. In total ten people were invited for the group discussion. The discussion group was sub-divided into three groups. Each of the sub-groups comprised a community head, head of women group and youth leader, as well as one assistant who helped in writing down what was discussed in the group. The moderator of the group discussion started by introducing the subject and each of the sub-groups was asked to discuss their opinions regarding the involvement of only one private firm in the provision of household waste management services and whether the quality of the services would be better if more private firms are involved. They were asked to design simple questions that can help gain information from the general public regarding the provision of household waste management services which involve only one private firm (i.e. the present situation) and the services that involve many private firms. And how much money the public would be willing to pay for the provision of household waste management services which involve many private firms. After the group discussions a questionnaire was drafted based on the report from the group discussions. The questionnaire draft was presented at a second meeting with the discussion group. The questionnaire draft was modified to meet the concerns raised by members of the discussion group. Three officials of the waste management authority were contacted and were asked to comment on the questionnaire draft. They suggested the inclusion of variables such as the activities of sanitary inspectors and the travel time to the nearest household waste collection point. The questionnaire was further modified based on the comments of the waste management authority officials. To check the suitability of the questionnaire, pre-test survey involving 30 randomly selected households was conducted. The respondents were asked to comment on any difficulty they face concerning interpreting the questions, as well as suggest ways of improving the questionnaire.

After the pre-test survey, some questions in the questionnaire (e.g. wording regarding the willingness to pay question and independent variables) were adjusted to capture concerns raised by survey assistants and respondents to the pre-test. The main survey was conducted during the months of June and July 2009. Six survey assistants were recruited and trained for 3 days. The assistants were fluent in the local language (Yoruba) of people in the study area. The Ilorin city was divided into three sub-divisions namely, the old residential area, the new residential area and the government reservation area. Eleven streets were randomly selected in each of the sub-divisions and ten households were randomly selected from each street. In total 330 households were involved in the survey (i.e. 110 in each sub-division). If a resident declined the questionnaire/ interview, or there was not an adult individual at the residence contacted, we proceeded to the next residence until the desired sample size of respondents was achieved. The questionnaires/interviews were administered at both weekdays and weekends, as well as during working hours and after working hours, to include as many categories of the population as possible during the survey period. The assistants visited the selected households twice either to remind them about the questionnaire or to collect the completed questionnaire. Three hundred and twelve questionnaires were handed out to the Ilorin residents, only 218 (70 \%) responded to the questionnaire after two reminders. All people (18) who had no formal education agreed to be interviewed. In total, 236 (72\%) responded to the survey and 235 of the responses were useable for statistical analysis. This reveals that $<1 \%$ of the responses were not included in the analysis which should not have a significant impact on the results.

\section{The willingness to pay question}

The willingness to pay question was the dichotomous choice format. The respondents were asked whether they would support a new residential waste management strategy that involves a government agency and many private firms to help increase frequency of residential waste collection in Ilorin city. The city will be classified into subareas and each of the area will be served by one private firm and a government agency. This should help improve 
the residential waste collection services in Ilorin. The respondents who said 'yes' were asked if they would still support the new waste management strategy if it would cost them $x$ Nigerian Naira (NGN) each month. The $x$ NGN corresponds to the amount of money $(50,100,150,200$, 250,300 , and $350 \mathrm{NGN}$ ) that were randomly assigned to the respondents. The respondents who were not in support of the new waste management strategy were asked to give the reason(s).

The respondents were asked a series of socio-economic questions (education, gender, income and household size). They were asked about their dwelling and the travel time from their residence to the nearest waste collection point. The respondents were asked whether the activities of sanitary inspectors were strongly felt in their areas and whether they were happy with private sector participation in household waste management.

The conceptual framework

In the course of consuming goods and services, people tend to maximize benefits and minimize costs (Garrod and Willis 1999). The urban residents' willingness to pay for residential waste management services that involve many private firms was explored in this study. It is proposed that each of the private firm selected by the government waste management authority through bidding method will be allocated a sub-area of Ilorin. The private firm will be involved in residential waste collection in only the area allocated to them under the supervision of government agency. It is expected that it will help improve the present situation of residential waste management in Ilorin which involve a single private firm providing residential waste management in the whole Ilorin city. The willingness to pay (i.e. the amount of money necessary to achieve a new utility level (Champ et al. 2003) of the respondents is expected to vary in accordance to the utility they get from the waste management. The respondent willingness to pay for waste management $\mathrm{WTP}_{\mathrm{wm}}$ can be expressed as:

$v\left(p, y-\mathrm{WTP}_{\mathrm{wm}}, q^{1} ; s\right)=v\left(p, y, q^{0} ; s\right)$

where $v($.$) is the indirect utility function, p$ is the price of composite good, $y$ the income, $q^{0}$ is the service provided by one private firm, $q^{1}$ is the service provided by many private firms and $s$ is other socio-economic attributes of the respondent. The $\mathrm{WTP}_{\mathrm{wm}}$ will depend on:

$\mathrm{WTP}_{\mathrm{wm}}=f\left(p, y, q^{1}-q^{0} ; s\right)$

Since $\mathrm{WTP}_{\mathrm{wm}}$ is latent, i.e. not observable. Therefore, let $I$ be the indicator variable, so that:

$$
\begin{array}{r}
I=1, \text { if } \mathrm{WTP}_{\mathrm{wm}}=\text { yes } \\
=0, \text { otherwise. }
\end{array}
$$

Expected effects of some factors on the respondent willingness to pay for improved residential waste management

\section{Price}

In accordance to economic theory of demand (Gravelle and Rees 2004) the higher the price the lower would be quantity of goods and services bought. In other words, the higher the payment amount the lower should be the demand for the improved residential waste management.

\section{Income}

One of the aims of residential waste management is to provide a clean environment and help improve environmental quality. The theory of demand for environmental goods assumes that the higher the income the more the demand for improved environmental quality is (Tietenberg and Lewis 2010).

\section{Education}

People who have many years of schooling are more likely to get access to information regarding the costs and benefits of improved residential waste management. Thus, people who have many years of schooling are more likely to pay for improved residential waste management.

\section{Gender}

According to the tradition of the people in the study area one of the roles of women is to keep the residential area clean. It is expected that men will less likely pay for improved residential waste management.

\section{Time}

People who use more time to travel to the present residential waste collection points will likely pay for improved waste management if it will help reduce the travel time.

\section{Household size}

Like in many developing countries, most of the households in the study area have only one 'bread winner' who fends for all members of the household. Therefore, larger households are less likely to pay for the improved household waste management. 


\section{Activities of sanitary inspectors}

Sanitary inspectors help to enforce laws regarding keeping the environment clean. In areas where sanitary inspectors are more active the areas should be clean enough to the satisfaction of residents. People who live in these areas are less likely to pay for a new type of residential waste management.

\section{Dwelling type}

People who live in single family-dwelling often have more space and greater potential to generate more quantity of household waste than people who live in multi-user dwelling. Thus, people who live in single-family dwelling are more likely to pay for improved residential waste management.

\section{Whether the respondent is happy with private waste management}

If people are happy with a thing they will likely ask for more. In other words, people who are happy with private sector participation in residential waste management are likely to pay for improved waste management.

The binary logit model

In this study, the household willingness to pay question was a dichotomous choice, i.e. 'yes'/'no' thus a binary logit model (Greene 2003) can be applied in the analysis of factors associated with respondent willingness to pay for improved residential waste management. The probability $P$ that the respondent will give a 'yes' response, i.e. willing to pay is given as follows:

$P[$ yes $]=\frac{1}{1+e^{-\beta x}}$

where $\beta$ is a vector of parameters to be estimated and $x$ is a vector of the respondent attributes. The probability that the respondent will give a 'no' response, i.e. not willing to pay is given as follows:

$$
\begin{aligned}
& P(\text { no })=1-P(\text { yes }) \\
& P[\text { no }]=\frac{1}{1+e^{\beta x}}
\end{aligned}
$$

Manipulation of (5) and (6), gives

$$
\begin{aligned}
& 1-P(\text { yes })=\frac{1}{1+e^{\beta x}} \\
& \frac{P(\text { yes })}{1-P(\text { yes })}=e^{\beta x}
\end{aligned}
$$

where $e^{\beta x}$ is the ratio of the probability of a 'yes' to the probability of a 'no' response. The logarithm of the odds ratio is given as follows:

$\ln \left[\frac{P(\text { yes })}{1-P(\text { yes })}\right]=\beta x$

$\mathrm{WTP}_{\mathrm{wm}}=\beta_{0}+\beta x_{1}+\cdots+\beta_{n} x_{n}+\varepsilon$

$\beta_{0}$ is the intercept, $\beta_{1}$ is the coefficient associated with the price $x_{1}$, and $\beta_{n}$ a vector of regression coefficients associated with other attributes of the respondent $x_{n}$ and $\varepsilon$ is the error term which is logistically distributed. Although the probit model can be applied in the present study the assumptions of the probit model, e.g. normal distribution and that the variance around the regression line is the same for all values of the predictor variance (homoscedasticity) could not be met. The Lagrange multiplier (LM) statistic was calculated as 115.337. This is asymptotically distributed as Chi-squared $X^{2}$ with 9 degrees of freedom. Given that $X_{0.01}^{2}(9)=21.67$, the hypothesis that the model is homoscedastic can be rejected at $1 \%$ statistical significant level. The test statistic for normality was computed as 11.600 with 2 degrees of freedom using LM test. Given that $X_{0.01}^{2}(2)=9.210$, the hypothesis that the error term is normally distributed can be rejected at $1 \%$ statistically significant level. These test results show that the assumptions required to use the probit model could not be satisfied. As an alternative to the probit model, the logit model was used. The binary logit model was estimated using LIMDEP NLOGIT version 4.0.1 statistical package (Econometric Software Inc, New York, USA. See, Table 3) to examine factors which influence the respondents $\mathrm{WTP}_{\mathrm{wm}}$. The mean willingness to pay $\mathrm{MWTP}_{\mathrm{wm}}$ was estimated as (Hanemann 1989):

$\mathrm{MWTP}_{\mathrm{wm}}=\frac{1}{\beta_{1}} * \ln \left(1+e^{B_{0}}\right)$

where $B_{1}$ is the estimated coefficient associated with the payment amount and $B_{0}$ is the sum of the estimated coefficients associated with the constant and other independent variables multiplied by their means. Explanation of variables that were used in the analysis is presented in Table 1. The variance inflation factors of each independent variable did not exceed 1.30 (see Table 1) and correlation between the variables did not exceed 0.32 (see Table 4) this shows that multicollinearity and collinearity are not serious problem in the estimated model.

\section{Results and discussion}

Sixteen percent of the respondents were not in support of the residential waste management that involves many private firms and $84 \%$ were in support. Of the respondents 
Table 1 Explanation of variables used in the model

\begin{tabular}{|c|c|c|c|c|}
\hline Variable & Description & Mean & $\%$ & VIF \\
\hline $\mathrm{WTP}_{\mathrm{wm}}$ & $\begin{array}{l}\text { Willingness to pay for improved services } \\
\begin{array}{l}\text { Yes }=1 \\
\text { No }=0\end{array}\end{array}$ & $\begin{array}{l}0.61 \\
0.39\end{array}$ & $\begin{array}{l}61 \\
39\end{array}$ & \\
\hline AMOUNT & $\begin{array}{l}\text { Prices }(50,100,150,200,250,300,350 \text { NGN) } \\
\text { associated with the respondents' } \mathrm{WTP}_{\mathrm{wm}} \\
50 \\
100 \\
150 \\
200 \\
250 \\
300 \\
350\end{array}$ & & $\begin{array}{r}100 \\
76 \\
56 \\
37 \\
19 \\
10 \\
4\end{array}$ & 1.11 \\
\hline INCO & Household income per year (NGN) & 441,322 & & 1.28 \\
\hline TIME & $\begin{array}{l}\text { Travel time from respondent's home to } \\
\text { to waste collection point (minutes) }\end{array}$ & 7.753 & & 1.12 \\
\hline EDUC & Number of years that the respondent had formal education & 14.7 & & 1.29 \\
\hline INSPEC & $\begin{array}{l}\text { Activities of sanitary inspectors are strongly felt in } \\
\text { my area: Yes }=1 \\
\text { No }=0\end{array}$ & $\begin{array}{l}0.17 \\
0.83\end{array}$ & $\begin{array}{l}17 \\
83\end{array}$ & 1.12 \\
\hline DWELL & $\begin{array}{l}\text { The type of house the respondent lives: } \\
\text { Single-family dwelling }=1 \\
\text { Multi-user dwelling }=0\end{array}$ & $\begin{array}{l}0.43 \\
0.57\end{array}$ & $\begin{array}{l}43 \\
57\end{array}$ & 1.24 \\
\hline GEND & $\begin{array}{c}\text { Respondent's gender }(\text { male }=1,0=\text { female }) \\
\text { Male } \\
\text { Female }\end{array}$ & $\begin{array}{l}0.57 \\
0.43\end{array}$ & $\begin{array}{l}57 \\
43\end{array}$ & 1.11 \\
\hline $\begin{array}{l}\text { HHOLD } \\
\text { PRIVAT }\end{array}$ & $\begin{array}{l}\text { Household size (number of persons) } \\
\text { Respondent is happy with private waste delivery } \\
\text { services } \\
\begin{array}{l}\text { Yes }=1 \\
\text { No }=0\end{array}\end{array}$ & $\begin{array}{r}0.59 \\
0.41\end{array}$ & $\begin{array}{c}59 \\
41\end{array}$ & $\begin{array}{l}1.12 \\
1.23\end{array}$ \\
\hline
\end{tabular}

The AMOUNT in \% is based on cumulative frequency

NGN1 US \$0.00649, VIF variance inflation factor

who were in support of the waste management $61 \%$ were willing to pay for the services and $39 \%$ were not willing to pay. The respondents who were willing to pay for the waste management had higher income and educational attainment while those who were not willing to pay had larger household (see Table 2). However, there was no difference between the travel time to waste collection point for the respondents who were willing to pay and those who were not willing to pay. In terms of coefficient of variation the respondents who were willing to pay had lesser disparity in the distribution of their income and educational attainment compared to the respondents who were not willing to pay (Table 2). The means were thus more representative of the means of the variables. This could account for the respondents' willingness to pay. The respondents who were
Table 2 Comparison of some socio-economic variables of the respondents

\begin{tabular}{llllll}
\hline Variable & \multicolumn{2}{l}{ Willing to pay } & & \multicolumn{2}{l}{ Unwilling to pay } \\
\cline { 2 - 3 } & Mean & CV \% & & Mean & CV \% \\
\hline INCO & 450,372 & 37.5 & & 427,419 & 43.0 \\
TIME & 7.8 & 37.4 & & 7.9 & 35.2 \\
EDUC & 15.1 & 14.9 & & 14.2 & 23.1 \\
HHOLD & 4 & 46.6 & & 6 & 43.4 \\
\hline
\end{tabular}

$C V$ coefficient of variation

not willing to pay had lesser disparity in the distribution of their household size compared to the respondents who were willing to pay. The mean was thus more representative of 


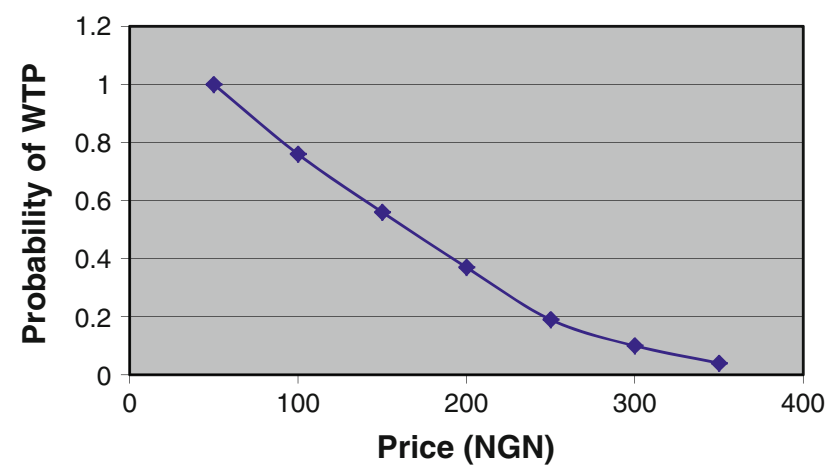

Fig. 1 Willingness to pay for waste management services

the mean of the variable. This could account for their not willing to pay.

All the respondents were willing to pay for the residential waste management at the price level of NGN50 (Fig. 1). 76, 56 and $10 \%$, respectively, were willing to pay NGN100, NGN150 and NGN300. The findings here is that the percentage of the respondents who were willing to pay for the waste management services decreased as the price of the waste management increased.

The respondents were willing to pay an average of NGN305 (US \$1.98) per month (see Table 3). This was $0.83 \%$ of the respondents' average monthly income. Since the human population of Ilorin was 766,000 (National Population Commission 2006) and the mean household size was five persons (see Table 1). The number of households in Ilorin should be 153,200. Aggregating the mean willingness to pay amount over the households, the total perceived welfare benefits for the improved waste management services in the Ilorin is estimated to be NGN $560,712,000$ (US $\$ 3,640,980$ ) each year. To examine the factors that might have influenced the respondents' willingness to pay for the improved residential waste management a binary logit model was estimated (Table 3). The likelihood ratio had a Chi-squared statistic of 1,045.458 and was statistically significant at $0.01 \%$, while the Hosmer-Lemeshow statistic had the $P$ value of 0.489 . More than $83 \%$ of the respondents were correctly predicted to be in the group to which they actually belonged by the estimated model. This reveals that the binary logit model displays a good fit.

The coefficients associated with income, education, dwelling type and whether the respondent is happy with private waste management had positive and statistically significant effects on the willingness to pay. The coefficients associated with the price, activities of sanitary inspectors, gender and household size had negative and statistically significant effects on the willingness to pay. The results imply that the respondents, who have more money, more years of schooling, reside in a single-family dwelling house and were happy with private participation
Table 3 Binary logit results for factors influencing willingness to pay

\begin{tabular}{|c|c|c|c|c|}
\hline Variable & Coeff. & SE & M. effects & Odds ratio \\
\hline Constant & 0.556 & 0.612 & & \\
\hline AMOUNT & $-0.019 * * *$ & 0.001 & -0.004 & 0.981 \\
\hline INCO & $0.000002 * *$ & 0.0000004 & 0.000 & 1.000 \\
\hline TIME & -0.018 & 0.033 & -0.004 & 0.982 \\
\hline EDUC & $0.196^{* * *}$ & 0.0331 & 0.041 & 1.217 \\
\hline INSPEC & $-1.483 * * *$ & 0.209 & -0.347 & 0.227 \\
\hline DWELL & $0.937^{* * * *}$ & 0.148 & 0.189 & 2.552 \\
\hline GEND & $-0.430 * *$ & 0.146 & -0.089 & 0.651 \\
\hline HHOLD & $-0.065 *$ & 0.0332 & -0.014 & 0.937 \\
\hline PRIVAT & $0.653 * * *$ & 0.169 & 0.137 & 1.921 \\
\hline \multicolumn{2}{|c|}{$\begin{array}{l}\text { Log likelihood function } \\
\text { Restricted log likelihood }\end{array}$} & \multicolumn{2}{|c|}{-690.404} & \\
\hline \multirow{2}{*}{\multicolumn{2}{|c|}{$\begin{array}{l}\text { Restricted log likelihood } \\
\text { Chi squared }\end{array}$}} & \multirow{2}{*}{\multicolumn{2}{|c|}{$\begin{array}{c}-1213.134 \\
1045.458\end{array}$}} & \\
\hline & & & & \\
\hline \multicolumn{2}{|c|}{ Prob[Chi squared > value] } & \multicolumn{2}{|c|}{$0.0000^{* * *}$} & \\
\hline \multicolumn{2}{|c|}{ McFadden Pseudo $R^{2}$} & \multicolumn{2}{|c|}{0.431} & \\
\hline & & 83.40 & & \\
\hline \multicolumn{2}{|c|}{$\begin{array}{l}\text { Hosmer-Lemeshow Chi-squared } \\
\quad P \text { value }=0.489\end{array}$} & \multicolumn{2}{|c|}{5.432} & \\
\hline \multicolumn{2}{|c|}{$\mathrm{MWTP}_{\mathrm{wm}}$} & \multicolumn{2}{|c|}{ NGN 304.848} & \\
\hline
\end{tabular}

$*, * *, * * * 0.05,0.01$ and 0.001 levels of statistical significance, respectively. M. Effects (Marginal effects) for discrete independent variables were calculated as the difference in the expected value of the dependent variable when the independent variable of interest takes the value zero and when it takes the value one while marginal effects for continuous independent variables were calculated at the mean of the independent variable of interest

in waste management, were more likely to pay for the residential waste management that involves many private firms. The respondents who were male, faced with higher prices for the services, resides in areas where the activities of sanitary inspectors were strong and have larger household were less likely to pay for the services. The coefficients associated with whether the respondent is happy with private waste management and dwelling type had the highest odds ratios (1.9 and 2.6, respectively). In other words, the respondents who were happy with private waste management and reside in single-family dwelling house type were one to about two times more likely to pay for the residential waste management. This implies that the coefficients associated with dwelling type and being happy with private waste management are not only statistically significant but are also important from management point of view. In terms of marginal effects, the respondents who were happy with private waste management and reside in single-family dwelling house type were 14 and $19 \%$ more likely to pay for the services, while the respondents who reside in areas which the activities of sanitary inspectors were strong were $35 \%$ less likely to pay for the residential 
waste management. The estimated income elasticity of demand for waste management is 0.218 . This implies that improvement in environmental quality is a necessity good. The coefficient associated with the travel time to the residential waste collection point had the expected sign; however, it was not statistically significant.

The results show that more than $60 \%$ of the respondents were willing to pay for the residential waste management. This suggests that if more private firms are involved in the provision of the waste management service more of the Ilorin residents might pay for the service. On the other hand, the success of the waste management service strategy would require a commitment on the part of the waste management authorities, private firms and the Ilorin residents. The prices that the respondents were willing to pay for the residential waste management vary widely. The higher the price the lower was the number of the respondents who were willing to pay and vice versa. The results reveal the demand for the residential waste management, i.e. the higher the price for the service, the smaller the number of people that would be willing to pay (see Fig. 1). The respondents were willing to pay only about $1 \%$ of their monthly income for the residential waste management. This is not surprising because the service contributes to environmental good, e.g. improvement in environmental quality. People often have less incentive to pay for an environmental good because it is impossible to prevent people who do not pay for the good from enjoying some of it benefits (Tietenberg and Lewis 2010). For the respondents who were not in support of the residential waste management strategy the most important reasons were that they raised doubt about the capacity of the waste management to successfully implement the strategy. They also raised concerns regarding the sustainability of the waste management strategy. These highlight the importance of bottom-top approach in designing the strategy because it should help improve the general public's confidence on the waste management authorities.

The results of the binary logit model show that the respondents were less likely to pay higher price for the residential waste management. A reason may be that individuals tend to maximize utility at least cost, hence the higher the price of the service the lower will be the demand for it. Similar result has been reported in other study by Rahji and Oloruntoba (2009). They found that households in Ibadan, Nigeria, were less willing to pay higher prices for improved solid waste services. Thus, for the residential waste management to be sustainable it is important to involve the stakeholders (residents, private firms and waste management authorities) in determining the price for the service. Because if the price is too high most of the residents may not pay for the service and if the price is too low the private firms may not have sufficient incentive for provision of effective waste management service. The respondents who have more money were more likely to pay for the residential waste management. This is not surprising because the more money an individual has the higher will be his/her purchasing power (Gravelle and Rees 2004). Similar results have been found in other study by Jin et al. (2006). They found that household income influences household's willingness to pay for solid waste management programmes in Macao, China. Although the income elasticity of demand for improvement in waste management is positive it is less than one. This suggests that improvement of environmental quality is a necessity good (i.e. it is needed by everyone in the society) but an increase in income will lead to an increase in the demand for waste management services.

The results of the study show that the respondents who have many years of schooling were more likely to pay for the residential waste management. Similar result has been reported in other study by Yusuf et al. (2007). In their study, they found that the individuals who have spent many years in schooling were more willing to pay for waste management services in Oyo state, Nigeria. Education gives people greater access to information regarding the future benefits of an improved waste management services. For example, people with more formal education may understand more easily how the services can offer access to a cleaner environment, improve environmental quality and a reduction in the risk of the incidence of environmental pollution related ailments. The Ilorin residents consist of people who have formal education and those who do not, this implies that it is important to increase access to information regarding benefits that the Ilorin residents can gain from the residential waste management.

The respondents who reside in areas where the activities of sanitary inspectors were strongly felt were less likely to pay for the residential waste management. A possible reason may be the stronger the sanitary inspection the higher should be the cost of illegal dumping of refuse, thus people should have less incentive to dump refuse. This might have helped in improving residential waste management in areas where activities of sanitary inspectors were strongly felt. Another possible reason may be that the private firm charged with the provision of the waste management was more effective in areas where the activities of the sanitary inspectors were strongly felt. People who reside in areas where the waste management service is effective should have less incentive to pay for a new type of waste management arrangement. This suggests that private firms that are involved in the provision of residential waste management would be more effective if waste management authorities could monitor the activities of the firms thoroughly.

The respondents who live in single-family house were more likely to pay for the residential waste management. It may be that people who live in a single-family house have less incentive to enjoy benefits of the services free of charge or pay less money for it (free-riding) than the people 
who live in a multi-family house. The respondents who were male were less likely to pay. This is not surprising because men in the study area are not often involved in residential waste disposal thus they should be less affected by ineffective waste management than women. Therefore, men have less incentive to pay for the service. This suggests that it is important for women to be actively involved in designing a residential waste management strategy. The respondents who have larger household were less likely to pay for the residential waste management. A reason may be that the more the number of persons in a family the more the mouth to feed is. Thus, the issue of waste management services might be given a lower priority in the family's budget. Similar finding has been reported in other study by Yusuf et al. (2007). The respondents who were happy with private waste management services were more likely to pay. A possible reason may be that people who were happy with the private provision of the services expect that if more private firms are involved it should help improve the service. The not statistically significant result shown for the coefficient associated with travel time to waste collection point suggests that both the respondents who use more time and those who less time to travel to waste collection points attach equal importance to residential waste management that involve many private firms.

Although in some Nigerian cities such as Lagos and Ibadan residents pay for residential waste management service (Longe et al. 2009; Rahji and Oloruntoba 2009; Yusuf et al. 2007), the waste management service has not been very successful. The residents do not often participate in negotiating prices for waste management service thus the service is either overvalued or undervalued. This study has applied willingness to pay method to elicit the value that Ilorin residents have for residential waste management service. This should provide waste management authorities the knowledge of the value that Ilorin residents have for residential waste management. It should also help the waste management authorities in negotiating price for waste management service with the private firms and in determining price that will be acceptable to most Ilorin residents to help reduce the incidence of illegal dumping of refuse. The results of the study have shown that sanitary inspectors have an important role to play in residential waste management. This should help waste management authorities in identifying areas in the Ilorin city where sanitary inspectors are not very effective and plan how to increase the effectiveness of sanitary inspectors in these areas.

\section{Conclusion}

The findings of the study revealed that Ilorin residents have willingness to pay for improved residential waste management. To improve the Ilorin residents' acceptance of the residential waste management strategy, one could provide facilities that increase access to information regarding the future benefits of involving more private firms in the provision of residential waste management. Women often play an important role in residential waste disposal in Ilorin, thus women should be more actively involved in designing the waste management strategy. It is important that the sanitary inspectors pay more attention to performance monitoring and accountability with regard to the private firms. The research findings can contribute to more understanding regarding the value that Ilorin residents have for residential waste management that involves many private firms.

Acknowledgments I thank all Ilorin residents who spent their valuable time in attending the survey. Appreciation goes to Emmanuel Animasaun of Malmö University for helping in collecting the data. I thank anonymous persons who reviewed this paper for their useful comments. This research received no specific grant from any funding agency in the public, commercial, or not-for-profit sectors.

\section{Appendix}

Table 4 Correlation matrix for factors influencing willingness to pay

\begin{tabular}{lcccccrrrr}
\hline & AMOUNT & INCO & TIME & EDUC & INSPEC & DWELL & GEND & HHOLD & PRIVAT \\
\hline AMOUNT & 1.00 & 0.09 & -0.05 & -0.03 & 0.03 & -0.06 & 0.06 & 0.18 & 0.04 \\
INCO & 0.09 & 1.00 & -0.01 & 0.31 & -0.01 & 0.27 & 0.13 & 0.002 & 0.17 \\
TIME & -0.05 & -0.01 & 1.00 & -0.16 & -0.18 & 0.003 & -0.05 & -0.02 & -0.14 \\
EDUC & -0.03 & 0.31 & -0.16 & 1.00 & 0.02 & 0.16 & 0.06 & 0.002 & 0.31 \\
INSPEC & 0.03 & -0.01 & -0.18 & 0.02 & 1.00 & -0.14 & 0.01 & -0.01 & 0.12 \\
DWELL & -0.06 & 0.27 & 0.001 & 0.16 & -0.14 & 1.00 & -0.15 & 0.09 & 0.11 \\
GEND & 0.06 & 0.13 & -0.06 & 0.06 & 0.01 & -0.15 & 1.00 & 0.03 & 0.08 \\
HHOLD & 0.18 & 0.002 & -0.02 & 0.002 & -0.01 & 0.09 & 0.03 & 1.00 & -0.12 \\
PRIVAT & 0.04 & 0.17 & -0.14 & 0.31 & 0.12 & 0.11 & 0.08 & -0.12 & 1.00 \\
\hline
\end{tabular}




\section{References}

Aderamo AJ (2000) Spatial pattern of intra-urban trips in Ilorin. Geostudies 1(1-2):47-57

Alta AA, Deshaz OJ (1996) Households demand for improved solid waste management, a case study of Gujarwala, Pakistan. World Dev 24(5):857-868

Anaman KA, Jair RM (2000) Contingent valuation of solid waste collection services for rural households in Brunei Darussalam. Singap Econ Rev 45(2):223-240

Awomuti AA (2008) An analysis of waste generation rate and pattern in Ilorin, Nigeria. Lapai Int J Manag Soc Sci 1(1):171-183

Bishop RC, Champ PA, Mullarkey DJ (1995) Contingent valuation. In: Bromley DW (ed) The handbook of environmental economics. Blackwell Publishers, Cambridge

Carson R (2004) Contingent valuation: a comprehensive bibliography and history. Edward Elgar, Cheltenham/Northampton

Champ PA, Boyle K, Brown TC (eds) (2003) A primer on nonmarket valuation. Kluwer Academic Publishers, Boston

Chuen-Khee P, Othman J (2010) Household demand for solid waste disposal options in Malaysia. Int J Hum Soc Sci 5(14):905-910

Driesen D (2006) Economic instruments for sustainable development. In: Richardson BJ, Wood S (eds) Environmental law for sustainability. Hart Publishing, Portland

Ezebilo EE (2010) Conservation of a leafy vegetable important for communities in the Nigerian rainforest. For Ecol Manage 259(8):1660-1665

Ezebilo EE, Animasaun ED (2011) Households' perceptions of private sector municipal solid waste management services: a binary choice analysis. Int J Environ Sci Technol 8(4):677-686

Ezebilo EE, Mattsson L, Afolami CA (2010) Economic value of ecotourism to local communities in the Nigerian rainforest zone. J Sustain Dev 3(1):51-60

Garrod G, Willis KG (1999) Economic valuation of the environment. Edward Elgar, Cheltenham

Gellynck X, Verhelst P (2007) Assessing instruments for mixed household solid waste collection services in the Flemish region of Belgium. Resour Conserv Recycl 49(4):372-387

Gravelle H, Rees P (2004) Micro-economics. Pearson Education Limited, England

Greene WH (2003) Econometric analysis, 5th edn. Prentice Hall, New Jersey

Hanemann M (1989) Welfare evaluations in contingent valuation experiments with discrete response data: reply. Am J Agric Econ 71(4):1057-1061

Hanley N, Shogren JF, White B (2007) Environmental economics in theory and practice. Palgrave Macmillan, New York

Imandoust SB, Gadam SN (2007) Are people willing to pay for river water quality, contingent valuation. Int $\mathrm{J}$ Environ Sci Technol 4(3):401-408

Jin J, Wang Z, Ran S (2006) Comparison of contingent valuation and choice experiment in solid waste management programs in Macao. Ecol Econ 57(3):430-441
Ku S-J, Yoo S-H, Kwak S-J (2009) Willingness to pay for improving the residential waste disposal system in Korea: a choice experiment study. Environ Manage 44(2):278-287

Kwara State of Nigeria (1997) Kwara state diary. Government Press, Ilorin

Longe EO, Ukpebor EF (2009) Survey of household waste generation and composition in Ojo Local Government Area, Lagos State, Nigeria. Int J Geotech Environ 1(1):41-54

Longe EO, Longe OO, Ukpebor EF (2009) People's perception on household solid waste management in Ojo Local Government Area in Nigeria. Iran J Health Sci Eng 3(3):209-216

Loomis JB (1993) Integrated public lands management: principles and applications to national forests, parks, wildlife refuges and BLM lands. Columbia University press, New York

McKerlie K, Knight N, Thorpe B (2006) Advancing extended producer responsibility in Canada. $\mathrm{J}$ Clean Prod 14(6-7):616-628

Mitchell RC, Carson RT (1989) Using surveys to value public goods: the contingent valuation method. Resources for the future, Washington D.C

National Population Commission (2006) Final Results of National Census, Kwara State. National Population Commission, Abuja, Nigeria

Niringiye A, Omortor DG (2010) Determinants of willingness to pay for solid waste management in Kampala city. Curr Res J Econ Theory 2(3):119-122

Palatnik R, Ayalon O, Shechter M (2005) Household demand for waste recycling services. Environ Manag 35(2):121-129

Rahji MAY, Oloruntoba EO (2009) Determinants of households' willingness to pay for private solid waste management services in Ibadan, Nigeria. Waste Manag Res 27(12):961-965

Shih LH, Chou TY (2011) Customer concerns about uncertainty and willingness to pay in leasing solar power system. Int J Environ Sci Technol 8(3):523-532

Slack RJ, Gronow JR, Voulvoulis N (2009) The management of household waste in the United Kingdom. J Environ Manag 90(1):36-42

Stafford SL (2002) The effect of punishment on firm compliance with hazardous waste regulations. $J$ Environ Econ Manag 44(2):290-308

Tietenberg T, Lewis L (2010) Environmental economics and policy. Pearson, New York

Wagner T, Arnold P (2008) A new model for solid waste management: an analysis of the Nova Scotia municipal solid waste strategy. J Clean Prod 16(4):410-421

Werner CM, Turner J, Shipman K, Twitchell FS, Dickson BR, Bruschke GV (1995) Commitment, behaviour and attitude change: an analysis of voluntary recycling. J Environ Psychol 15(3): 197-208

Yusuf SA, Salimonu KK, Ojo OT (2007) Determinants of willingness to pay for improved household waste management in Oyo State, Nigeria. Res J Appl Sci 2(3):233-239 